\title{
A Multidisciplinary Approach to Assess the Environmental Vulnerability at Local Scale in Context of Climate Change (Pilot Study in Upper Draa Valley, South Morocco)
}

\author{
Ahmed Karmaoui*, Mohammed Messouli, Issam Ifaadassan, Mohammed Yacoubi Khebiza
}

LHEA (URAC 33), Department of Environmental Sciences, Faculty of Sciences Semlalia, Cadi Ayyad University, Marrakech, Morocco

\begin{abstract}
In this paper, we analyze different aspects and indicators for assessing environmental vulnerability in Upper Draa Valley (pre-Sahara of Morocco). We began this study by realization of a detailed qualitative analysis based on the calculations of 50 indicators of the environmental vulnerability index (EVI), which is developed by Stockholm Environment Institute (SEI). EVI results allow us to classify the region as a vulnerable area to climate change and anthropogenic impacts. This results show also that water and population indicators influencing the existence of their oasean ecosystems. To analyze the water vulnerability under social and climatic scenarios, we used WEAP program, that predicting urban water demand and the SDSM model which traces the simulations of future climate by forcing the model with two IPCC greenhouse gases scenarios (A2 and B2). The outputs of the models (EVI, WEAP, SDSM) serves as a basis of the "Integrative Science for Society and the Environment" (ISSE) model developed by ILTER in 2007 , leading to a holistic understanding of vulnerability, in a coupled human-environment dimension.
\end{abstract}

Keywords: Environmental vulnerability; EVI; WEAP; SDSM; ISSE; Climate change; Anthropogenic factors

\section{Introduction}

Impacts of global changes on ecosystems have already been observed [1-3], these changes were recognized also in agro-systems, which results in an increased vulnerability. The agriculture is the mainstay of most African economies and the vast majority of the region's poor lives and works in rural area [4]. The climatic conditions impend to become less favorable for agricultural activity in many regions of the world [5], since the climate is a key factor in water availability, precipitation, in particular, greatly influences the amount of water. The combined effect of projected increase in water demand and decrease in water availability will be dramatic in northern Africa, where already today water resources are exploited beyond thresholds of sustainability [6]. The temperature factor influences also the water availability in arid region a greater amount of water is lost from the Earth's surface and returned to the atmosphere through evapotranspiration. This is especially true for the south of the High Atlas Mountains (Morocco), where the Upper Draa Valley is located. Here, a highly variable precipitation and large evaporation losses cause already today major water availability problems [7]. The Upper Draa Valley is the most vulnerable to these changes because of the high dependence of the population on the ecosystem services. In this paper, we assess the arid ecosystem vulnerability of Moroccan pre-Sahara. The vulnerability concept developed here; integrate results from four explicit models (Table 1), for analyzing the state of ecological and socio-economical sectors. A sustainable management of the resource can be assured, if the impacts of future climatic changes and water availability are assessed. For this, we have used the two models, firstly the Statistical Downscaling Model (SDSM) and secondly the Water Evaluation and planning System (WEAP). To assess the environmental vulnerability, we used the environmental vulnerability index (EVI), which leads a detailed diagnosis of the Upper Draa Valley environment (Figure 1).

In order to solve present and possible future problems with regard to freshwater supply, an interdisciplinary and holistic approach is clearly necessary [8]. This approach is also applicable for degraded ecosystems, erosion of biodiversity, soil quality and droughts.
Concerning scenario assessments and the description of human-nature systems in general the European Environment Agency (EEA) proposed the use of a framework, which distinguished driving forces, pressures, states, impacts and responses [9], known as DPSIR. Its main purpose is giving a structure in which to present system indicators to policy makers on environmental impacts and on impacts of political actions [7]. In Morocco the use of the DPSIR framework is promoted as well. In the Ziz catchment, neighboring the Draa catchment, an environmental risk assessment following the DPSIR framework is currently carried out [10]. Increasing demands on natural resources or ecosystem services, extensive changes in land use are presenting challenges to our understanding of how the systems on which we depend will be altered by changes in climate, biodiversity, environmental stressors. To address these impacts we need to understand how we will operate in the coming years, and what we can do to sustain. To meet these challenges we require a multidisciplinary approach integrating society and environment at multiple scales. This interdisciplinary approaches lead to understand change in the context of integrated social and ecological systems. A new fundamental research initiative is edited, is the Integrative Science for Society and the Environment (ISSE). This model provides a means to tackle multidisciplinary questions such as:

$$
\begin{array}{ll}
\checkmark & \text { Which indicators are most vulnerable to climate change? } \\
\checkmark & \text { Which socio-economical sectors are the most vulnerable? }
\end{array}
$$

*Corresponding author: Ahmed K, Department of Environmental Sciences, Cad Ayyad University, Marrakech, Morocco, Tel: +212-524-43-46-49; Fax: +212-524-4367-69; E-mail: karmaoui.ahmed@gmail.com

Received December 03, 2014; Accepted December 10, 2014; Published December 20, 2014

Citation: Karmaoui A, Messouli M, Ifaadassan I, Khebiza MY (2014) A Multidisciplinary Approach to Assess the Environmental Vulnerability at Loca Scale in Context of Climate Change (Pilot Study in Upper Draa Valley, South Morocco). Global J Technol Optim 6: 167. doi: 10.4172/2229-8711.1000167

Copyright: (c) 2014 Karmaoui A, et al. This is an open-access article distributed under the terms of the Creative Commons Attribution License, which permits unrestricted use, distribution, and reproduction in any medium, provided the original author and source are credited. 
Citation: Karmaoui A, Messouli M, Ifaadassan I, Khebiza MY (2014) A Multidisciplinary Approach to Assess the Environmental Vulnerability at Local Scale in Context of Climate Change (Pilot Study in Upper Draa Valley, South Morocco). Global J Technol Optim 6: 167. doi: 10.4172/22298711.1000167

Page 2 of 11

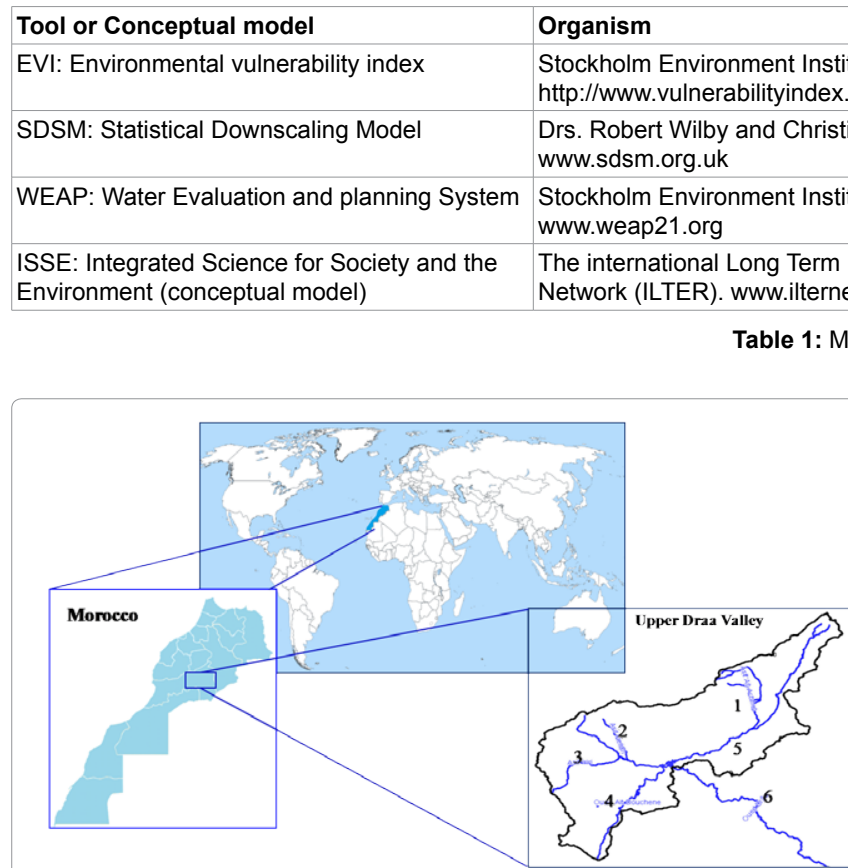

Figure 1: Location map of Upper Draa Valley. 1:Asif Ait Achmet, 2: Asif Mellah, 3: Asif Iriri, 4 :Oued ait Douchene, 5: Oued Dadès and 6: Oued Draa.

$\checkmark \quad$ Which scenario of climate change (A2 or B2) is the least harmful for a sector?

To assess vulnerability, we follow the steps proposed by, the Belfer Centre for Science and International Affairs of Harvard University, and they are:

$\checkmark \quad$ define the area of interest,

$\checkmark \quad$ understand the research field and its contents,

$\checkmark$ find out who is vulnerable in relation to what,

$\checkmark \quad$ develop a causal model of vulnerability,

$\checkmark \quad$ find indicators that will be the components of vulnerability,

$\checkmark$ determine the weighting factors and combine indicators,

$\checkmark \quad$ assess future vulnerability,

To complete these steps we combined the models mentioned in Table 1. The paper summaries the concepts of the framework that was developed for a vulnerability assessment, integrating and explaining the different tools used to quantify the elements of vulnerability, and how we integrate these elements into a conceptual model. The first tool used is the EVI; it is a numerical index that reflects the status of a country or a region's environmental vulnerability. The index was determined for anthropogenic, meteorological, biological, and geological events and for general characteristics. The overall environmental vulnerability Index (EVI) for Upper Draa Valley was determined by the calculating of 50 indicators. The evolution and the trend of climate was traced using the statistical downscaling models (SDSM) model under the A2 and B2 scenarios of climate change, these two scenarios are closest to the trajectory of the evolution of Moroccan society and changes associated with climate indicators [11]. They are extensively used today in the modeling works realized by the most comprehensive coupled models [12]. The existence of this ocean region is related to the presence and

\begin{tabular}{l} 
Principal objectives \\
Is a model reflecting the status of a region's environmental \\
vulnerability \\
$\begin{array}{l}\text { Assess the impact of local climate change through a robust } \\
\text { technique statistical downscaling }\end{array}$ \\
$\begin{array}{l}\text { Identify water resource management options under scenarios of } \\
\text { climate change and socio-economic }\end{array}$ \\
Study the environment in its social dimension \\
\hline
\end{tabular}

\section{Principal objectives}

Is a model reflecting the status of a region's environmental technique statistical downscaling

dentify water resource management options climate change and socio-economic

ical Research

used in this paper.

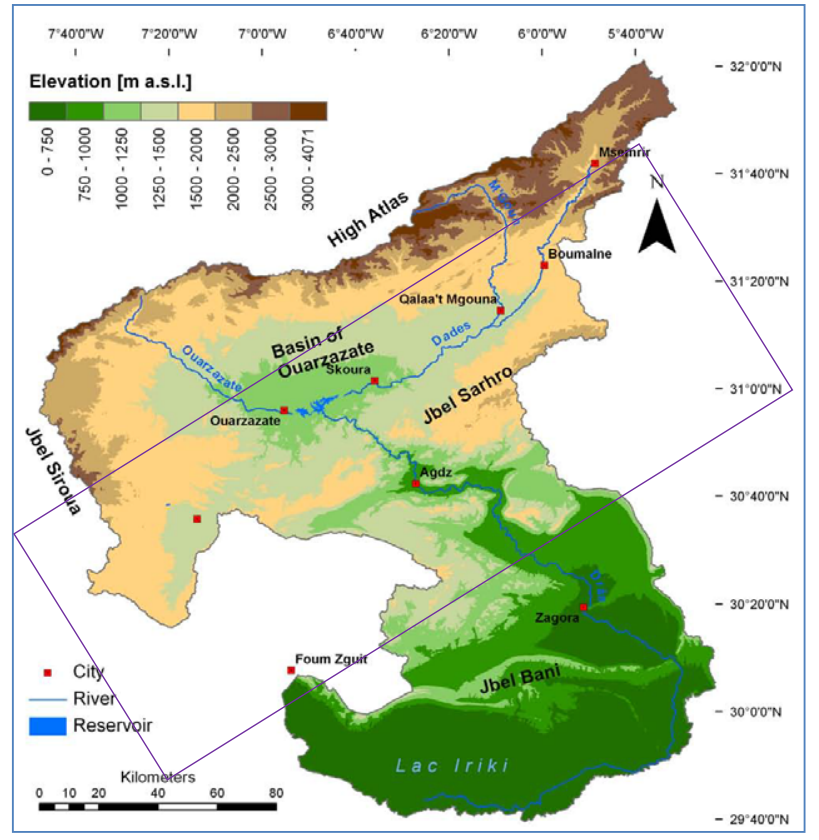

Figure 2: Digital Terrain Model (DTM) of Draa Valley [15].

use of water in desert environments. The water vulnerability assessment in this region is made by the Water Evaluation and planning System (WEAP). The outputs of these three models (EVI, WEAP, SDSM) serves as a basis of the ISSE model, leading to a holistic understanding of vulnerability, in a coupled human-environment dimension.

\section{Materials and Methods}

\section{Study area}

The Upper Draa valley is a semiarid area where groundwater recharge is low and strongly depending on the limestone covered High Atlas Mountains which represent only $20 \%$ of the Upper Draa catchment [13]. The geology of UDV is determined by three of the five major geological structures of Morocco [14]: Anti-Atlas, the High Atlas and the pre-Sahara. This strip of land is subject to two dynamics: wind erosion and the effects of river inputs. The Draa basin with an area of $115,000 \mathrm{~km}^{2}$ (Figure 2), the Draa River reaches the Atlantic Ocean in a continuing flow only during some very exceptional flood events [13]. This catchment is limited in the north by the southern slope of the High Atlas range culminating between 2,000 $\mathrm{m}$ and 4,000 $\mathrm{m}$ a.s.l. (Jbel Toubkal: 4,167 $\mathrm{m}$ a.s.l. and Jbel M'Goun: 4,071 $\mathrm{m}$ a.s.l.). With an altitude around 1,100 $\mathrm{m}$ a.s.l. the relatively flat topography of the Ouarzazate basin contrasts with the surrounding mountains [13]. 
Citation: Karmaoui A, Messouli M, Ifaadassan I, Khebiza MY (2014) A Multidisciplinary Approach to Assess the Environmental Vulnerability at Local Scale in Context of Climate Change (Pilot Study in Upper Draa Valley, South Morocco). Global J Technol Optim 6: 167. doi: 10.4172/22298711.1000167

Page 3 of 11

\begin{tabular}{|c|c|c|c|c|c|c|}
\hline $\mathbf{N}^{\circ}$ & Type & Category & $\begin{array}{l}\text { Sub- } \\
\text { Index }\end{array}$ & Description & Score & Unit \\
\hline 1 & Wind & Weather \& climate & $\begin{array}{l}\text { CC } \\
D \\
\text { CCD }\end{array}$ & $\begin{array}{l}\text { Average annual excess wind over the last five years (summing speeds } \\
\text { on days during which the maximum recorded wind speed is greater than } \\
20 \% \text { higher than the } 30 \text { year average maximum wind speed for that month) } \\
\text { averaged over all reference climate stations. }\end{array}$ & 1 & days/yr \\
\hline 2 & Dry & Weather \& climate & $\begin{array}{l}\text { CC } \\
D \\
A F \\
W \\
C C D\end{array}$ & $\begin{array}{l}\text { Average annual rainfall deficit }(\mathrm{mm}) \text { over the past } 5 \text { years for all months with } \\
>20 \% \text { lower rainfall than the } 30 \text { year monthly average, averaged over all } \\
\text { reference climate stations. }\end{array}$ & 2 & $\mathrm{~mm} / \mathrm{station} / \mathrm{yr}$ \\
\hline 3 & Wet & Weather \& climate & $\begin{array}{l}\text { CC } \\
D \\
A F \\
W \\
C C D\end{array}$ & $\begin{array}{l}\text { Average annual excess rainfall }(\mathrm{mm}) \text { over the past } 5 \text { years for all months } \\
\text { with }>20 \% \text { higher rainfall than the } 30 \text { year monthly average, averaged over } \\
\text { all reference climate stations. }\end{array}$ & 1 & $\mathrm{~mm} / \mathrm{station} /$ year \\
\hline 4 & Hot & Weather \& climate & $\begin{array}{l}\text { CC } \\
D \\
\text { CCD }\end{array}$ & $\begin{array}{l}\text { Average annual excess heat (degrees Farenheit) over the past } 5 \text { years } \\
\text { for all days more than } 9 \mathrm{~F}\left(5^{\circ} \mathrm{C}\right) \text { hotter than the } 30 \text { year mean monthly } \\
\text { maximum, averaged over all reference climate stations. }\end{array}$ & 4 & degrees/yr \\
\hline 5 & Cold & Weather \& climate & D & $\begin{array}{l}\text { Average annual heat deficit (degrees) over the past } 5 \text { years for all days } \\
\text { more than } 5^{\circ} \mathrm{C} \text { cooler than the } 30 \text { year mean monthly minimum, averaged } \\
\text { over all reference climate stations. }\end{array}$ & 3 & degrees/yr \\
\hline 6 & SST & Weather \& climate & $\begin{array}{l}\text { CC } \\
\text { AF } \\
\text { CBD }\end{array}$ & $\begin{array}{l}\text { Average annual deviation in Sea Surface Temperatures (SST) in the last } 5 \\
\text { years in relation to the } 30 \text { year monthly means (1961-1990) }\end{array}$ & NA & degrees/yr \\
\hline 7 & Volcano & Geology & $\mathrm{D}$ & $\begin{array}{l}\text { Cumulative volcano risk as the weighted number of volcanoes with the } \\
\text { potential for eruption greater than or equal to a Volcanic Explosively Index } \\
\text { of } 2 \text { (VEI } 2 \text { ) within } 100 \mathrm{~km} \text { of the country land boundary (divided by the area } \\
\text { of land). }\end{array}$ & 1 & $\begin{array}{l}\text { VEI Units/million } \\
\text { sq km }\end{array}$ \\
\hline 8 & Earth-quake & Geology & D & $\begin{array}{l}\text { Cumulative earthquake energy within } 100 \mathrm{~km} \text { of country land boundaries } \\
\text { measured as Local Magnitude }(\mathrm{ML}) \geq 6.0 \text { and occurring at a depth of less } \\
\text { than or equal to fifteen } \mathrm{km}(\leq 15 \mathrm{~km} \text { depth) over } 5 \text { years (divided by land } \\
\text { area) }\end{array}$ & 1 & $\begin{array}{l}\text { Number } M L>=6 \\
\text { Depth }<=15 \mathrm{~km}\end{array}$ \\
\hline 9 & Tsunami & Geology & $\mathrm{D}$ & $\begin{array}{l}\text { Number of tsunamis or storms surges with run-up greater than } 2 \text { metres } \\
\text { above Mean High Water Spring tide (MHWS) per 1000km coastline since } \\
1900\end{array}$ & 1 & $\begin{array}{l}\text { Number since } 1900 \\
>2 \text { m run-up }\end{array}$ \\
\hline 10 & Slides & Geology & D & $\begin{array}{l}\text { Number of slides recorded in the last } 5 \text { years (EMDAT definitions), divided } \\
\text { by land area }\end{array}$ & 1 & $\begin{array}{l}\text { Slides/million sq } \\
\mathrm{km} \text { land }\end{array}$ \\
\hline 11 & Land & Geography & $\begin{array}{l}\text { CC } \\
\text { CBD }\end{array}$ & Total land area $\left(\mathrm{km}^{2}\right)$ & 4 & $\mathrm{sq} \mathrm{km}$ \\
\hline 12 & Dispersion & Geography & $\begin{array}{l}\text { CC } \\
\text { CBD }\end{array}$ & Ratio of length of borders (land and maritime) to total land area & 4 & $\mathrm{~km} / 1000 \mathrm{sq} \mathrm{km}$ \\
\hline 13 & Isolation & Geography & CBD & Distance to nearest continent $(\mathrm{km})$ & 6 & $\mathrm{~km}$ \\
\hline 14 & Relief & Geography & $\begin{array}{l}\text { CC } \\
\text { CCD } \\
\text { CBD }\end{array}$ & Altitude range (highest point subtracted from the lowest point in country) & 3 & $\mathrm{~m}$ \\
\hline 15 & Lowlands & Geography & $\begin{array}{l}\text { CC } \\
\text { CCD } \\
\text { CBD }\end{array}$ & Percentage of land area less than or equal to $50 \mathrm{~m}$ above sea level & 1 & $\%$ \\
\hline 16 & Borders & Geography & CBD & Number of land and sea borders (including EEZ) shared with other countries & 1 & number \\
\hline 17 & Imbalance & & & $\begin{array}{l}\text { Ecological Imbalance as weighted average change in trophic level since } \\
\text { fisheries began (for trophic level slice } \leq 3.35 \text { ) }\end{array}$ & ND & \\
\hline 18 & Openness & Resources \& Services & $\begin{array}{l}\mathrm{AF} \\
\mathrm{CBD}\end{array}$ & $\begin{array}{l}\text { Average annual USD freight imports over the past } 5 \text { years by any means per } \\
\mathrm{km}^{2} \text { land area }\end{array}$ & 1 & $\begin{array}{l}\text { USD Thousands } \\
\text { sq km land }\end{array}$ \\
\hline 19 & Migratory & Resources \& Services & $\begin{array}{l}\mathrm{AF} \\
\mathrm{CBD}\end{array}$ & $\begin{array}{l}\text { Number of known species that migrate outside the territorial area at any time } \\
\text { during their life spans (including land and all aquatic species)/area of land }\end{array}$ & 2 & $\begin{array}{l}\text { Spp/1000 sq km } \\
\text { land }\end{array}$ \\
\hline 20 & Endemics & Resources \& Services & CBD & Number of known endemic species per million square $\mathrm{km}$ land area & 6 & $\begin{array}{l}\mathrm{Spp} / 1,000,000 \mathrm{sq} \\
\mathrm{km} \text { land }\end{array}$ \\
\hline 21 & $\begin{array}{l}\text { Introduc- } \\
\text { tions }\end{array}$ & Resources \& Services & $\begin{array}{l}\mathrm{AF} \\
\mathrm{CBD}\end{array}$ & Number of introduced species per 1000 square $\mathrm{km}$ of land area & 2 & $\begin{array}{l}\text { Spp/1,000 sq km } \\
\text { land }\end{array}$ \\
\hline 22 & Endanger-ed & Resources \& Services & CBD & $\begin{array}{l}\text { Number of endangered and vulnerable species per } 1000 \mathrm{sq} \mathrm{km} \text { land area } \\
\text { (IUCN definitions) }\end{array}$ & 3 & $\begin{array}{l}\text { Spp/1,000 sq km } \\
\text { land }\end{array}$ \\
\hline 23 & Extinctions & Resources \& Services & $\begin{array}{l}\mathrm{AF} \\
\mathrm{CBD}\end{array}$ & $\begin{array}{l}\text { Number of species known to have become extinct since } 1900 \text { per } 1000 \text { sq } \\
\text { km land area (IUCN definitions). }\end{array}$ & 4 & $\begin{array}{l}\text { Spp/1,000 sq km } \\
\text { land }\end{array}$ \\
\hline 24 & Vegetation & Resources \& Services & $\begin{array}{l}\mathrm{AF} \\
\mathrm{CBD}\end{array}$ & $\begin{array}{l}\text { Percentage of natural and regrowth vegetation cover remaining (include } \\
\text { forests, wetlands, prairies, tundra, desert and alpine associations). }\end{array}$ & ND & $\%$ of original cover \\
\hline 25 & Loss Veg & Resources \& Services & $\begin{array}{l}\text { AF } \\
\text { W } \\
\text { CCD } \\
\text { CBD }\end{array}$ & Net percentage change in natural vegetation cover over the last five years & 5 & $\begin{array}{l}\% \text { change } \\
(-\mathrm{ve}=\text { loss })\end{array}$ \\
\hline
\end{tabular}


Citation: Karmaoui A, Messouli M, Ifaadassan I, Khebiza MY (2014) A Multidisciplinary Approach to Assess the Environmental Vulnerability at Local Scale in Context of Climate Change (Pilot Study in Upper Draa Valley, South Morocco). Global J Technol Optim 6: 167. doi: 10.4172/22298711.1000167

Page 4 of 11

\begin{tabular}{|c|c|c|c|c|c|c|}
\hline 26 & Fragment & Resources \& Services & $\begin{array}{l}\mathrm{AF} \\
\mathrm{CBD}\end{array}$ & Total length of all roads in a country divided by land area & 1 & $\mathrm{~km} / \mathrm{sq} \mathrm{km}$ \\
\hline 27 & Degrada-tion & Resources \& Services & $\begin{array}{l}\text { W } \\
\text { CCD }\end{array}$ & $\begin{array}{l}\text { Percent of land area that is either severely or very severely degraded (FAO/ } \\
\text { AGL Terrastat definitions) }\end{array}$ & 5 & $\%$ \\
\hline 28 & Reserves & Resources \& Services & $\begin{array}{l}\text { AF } \\
\text { W } \\
\text { CBD }\end{array}$ & Percent of terrestrial land area legally set aside as no take reserves & 1 & $\%$ of land area \\
\hline 29 & MPA & Resources \& Services & $\begin{array}{l}\mathrm{AF} \\
\mathrm{CBD}\end{array}$ & $\begin{array}{l}\text { Percentage of continental shelf legally designated as marine protected } \\
\text { areas (MPAs) }\end{array}$ & NA & $\%$ \\
\hline 30 & Farming & Resources \& Services & $\begin{array}{l}\text { AF } \\
\text { W }\end{array}$ & $\begin{array}{l}\text { Annual tonnage of intensively farmed animal products (includes aquaculture, } \\
\text { pigs, poultry) produced over the last five years per square km land area. }\end{array}$ & 5 & $\mathrm{t} / \mathrm{sq} \mathrm{km} / \mathrm{yr}$ \\
\hline 31 & Fertilizers & Resources \& Services & $\begin{array}{l}\mathrm{HH} \\
\mathrm{AF} \\
\mathrm{W}\end{array}$ & $\begin{array}{l}\text { Average annual intensity of fertiliser use over the total land area over the } \\
\text { last } 5 \text { years. }\end{array}$ & 2 & $\mathrm{~kg} / \mathrm{sq} \mathrm{km} / \mathrm{yr}$ \\
\hline 32 & Pesticides & Resources \& Services & $\begin{array}{l}\mathrm{HH} \\
\mathrm{AF}\end{array}$ & $\begin{array}{l}\text { Average annual pesticides used as } \mathrm{kg} / \mathrm{km} 2 / \text { year over total land area over } \\
\text { last } 5 \text { years. }\end{array}$ & 2 & $\mathrm{~kg} / \mathrm{sq} \mathrm{km} / \mathrm{yr}$ \\
\hline 33 & Biotech & Resources \& Services & AF & $\begin{array}{l}\text { Cumulative number of deliberate field trials of genetically modified } \\
\text { organisms conducted in the country since } 1986\end{array}$ & 1 & Total number trials \\
\hline 34 & Fisheries & Resources \& Services & AF & Average ratio of productivity: fisheries catch over the last 5 years & 5 & $\begin{array}{l}\mathrm{tC} / \mathrm{sq} \mathrm{km} / \mathrm{yr}: \mathrm{t} \text { fish/ } \\
\mathrm{sq} \mathrm{km/yr}\end{array}$ \\
\hline 35 & Fish effort & Resources \& Services & AF & $\begin{array}{l}\text { Average annual number of fishers per kilometer of coastline over the last } 5 \\
\text { years }\end{array}$ & 1 & fishers/yr/km coast \\
\hline 36 & Water & Resources \& Services & $\begin{array}{l}\mathrm{HH} \\
\mathrm{AF} \\
\mathrm{CCD}\end{array}$ & $\begin{array}{l}\text { Average annual water usage as percentage of renewable water resources } \\
\text { over the last } 5 \text { years }\end{array}$ & 7 & $\%$ \\
\hline 37 & Air & Resources \& Services & $\mathrm{HH}$ & Average annual SO2 emissions over the last 5 years & 1 & $\mathrm{t} / \mathrm{sq} \mathrm{km/yr}$ \\
\hline 38 & Waste & Resources \& Services & -- & $\begin{array}{l}\text { Average annual net amount of generated and imported toxic, hazardous and } \\
\text { municipal wastes per square } \mathrm{km} \text { land area over the last } 5 \text { years }\end{array}$ & 1 & $\mathrm{t} / \mathrm{km} 2 / \mathrm{yr}$ \\
\hline 39 & Treatment & Resources \& Services & $\begin{array}{l}\mathrm{HH} \\
\mathrm{W}\end{array}$ & $\begin{array}{l}\text { Mean annual percent of hazardous, toxic and municipal waste effectively } \\
\text { managed and treated over the past } 5 \text { years. }\end{array}$ & 7 & $\%$ \\
\hline 40 & Industry & Resources \& Services & & $\begin{array}{l}\text { Average annual use of electricity for industry over the last } 5 \text { years per } \\
\text { square } \mathrm{km} \text { of land }\end{array}$ & 1 & toe $/ \mathrm{km}^{2}$ \\
\hline 41 & Spills & Resources \& Services & -- & $\begin{array}{l}\text { Total number of spills of oil and hazardous substances greater than } 1000 \\
\text { liters on land, in rivers or within territorial waters per million km coast during } \\
\text { the last five years }\end{array}$ & 1 & $\begin{array}{l}\text { Number of spills/ } \\
\text { million km coasts }\end{array}$ \\
\hline 42 & Mining & Resources \& Services & -- & $\begin{array}{l}\text { Average annual mining production (include all surface and subsurface } \\
\text { mining and quarrying) per km2 of land area over the past } 5 \text { years. }\end{array}$ & 4 & $\mathrm{t} / \mathrm{km}^{2} / \mathrm{yr}$ \\
\hline 43 & Sanitation & Resources \& Services & $\begin{array}{l}\mathrm{HH} \\
\mathrm{W}\end{array}$ & Density of population without access to safe sanitation (WHO definitions) & 5 & people/km² \\
\hline 44 & Vehicles & Resources \& Services & -- & Number of vehicles per square km of land area (most recent data) & 1 & vehicles $/ \mathrm{km}^{2}$ \\
\hline 45 & Density & $\begin{array}{l}\text { Human } \\
\text { Populations }\end{array}$ & $\begin{array}{l}\text { CC } \\
D \\
W\end{array}$ & Total human population density (number per km2 land area) & 1 & people $/ \mathrm{km}^{2}$ \\
\hline 46 & Growth & $\begin{array}{l}\text { Human } \\
\text { Populations }\end{array}$ & W & Annual human population growth rate over the last 5 years & 6 & $\%$ \\
\hline 47 & Tourists & $\begin{array}{l}\text { Human } \\
\text { Populations }\end{array}$ & -- & $\begin{array}{l}\text { Average annual number of international tourists per } \mathrm{km} 2 \text { land over the past } \\
5 \text { years. }\end{array}$ & 7 & people $/ \mathrm{km}^{2} / \mathrm{yr}$ \\
\hline 48 & Coastal & $\begin{array}{l}\text { Human } \\
\text { Populations }\end{array}$ & $\begin{array}{l}\text { CC } \\
D\end{array}$ & $\begin{array}{l}\text { Density of people living in coastal settlements (i.e. with a city centre within } \\
100 \mathrm{~km} \text { of any maritime or lake* coast). }\end{array}$ & NA & people $/ \mathrm{km}^{2}$ \\
\hline 49 & Agreements & $\begin{array}{l}\text { Human } \\
\text { Populations }\end{array}$ & -- & Number of environmental treaties in force in a country & 1 & treaties \\
\hline 50 & Conflicts & $\begin{array}{l}\text { Human } \\
\text { Populations }\end{array}$ & -- & $\begin{array}{l}\text { Average number of conflict years per decade within the country over the } \\
\text { past } 50 \text { years. }\end{array}$ & 1 & $\begin{array}{l}\text { Average conflict } \\
\text { years/decade }\end{array}$ \\
\hline
\end{tabular}

Table 2: Summary of the 50 environmental vulnerability indicators of the Upper Draa Valley (UDV), were 13 indicators of Climate Change (CC), 19 of Biodiversity (CBD), 12 referring Water (W), 20 about Agriculture / Fisheries (AF), 6 for Human Health Aspects (HH), 11 Desertification (CCD) and 11 for Exposure to Natural Disasters (D). ND means no data and NA indicates not applicable to the Upper Draa Valley.

The main administrative units are the provinces of Ouarzazate and one part of Tinghir (is a neighboring province). According to the classification of Koeppen, Draa valley has an arid desert climate and is hot. The hydrology of the Upper Draa Valley (UDV) is controlled principally by two rivers (Ouarzazate and Dadès). Theses Rivers fed the Mansour Eddahbi dam (downstream of the UDV) which was constructed in 1972 with an initial capacity of 583 million $\mathrm{m}^{3}$. The Mansour Eddahbi Dam is a way to tap water to generate hydroelectric power, control floods. However, the Mansour Eddahbi experiencing a major problem is the siltation. Indeed, the capacity was reduced by approximately $25 \%$ to 438 million $\mathrm{m}^{3}$ (in 1998) due to siltation; This corresponds to a mean erosion rate of 5,6t/ha/year [8]. The Draa Valley is mainly rural and its economy remains highly dependent on irrigated agriculture [16]. The agriculture challenges the extension of Bayoud disease (Fusarium oxysporum F. sp. Albedinis), a soil fungus that attacks the best varieties of date palm. Over the past decade Moroccan oasis space decreased by $34 \%$ of its production of dates [17], partly due to the spread of this fungus.

\section{Methodology}

In this paper the ISSE-framework was adopted to provide indicators about long term environmental vulnerability. With regard 
Citation: Karmaoui A, Messouli M, Ifaadassan I, Khebiza MY (2014) A Multidisciplinary Approach to Assess the Environmental Vulnerability at Local Scale in Context of Climate Change (Pilot Study in Upper Draa Valley, South Morocco). Global J Technol Optim 6: 167. doi: 10.4172/22298711.1000167

to environmental vulnerability, the ISSE framework can be considered as a causal chain starting with external factors (climate, globalization, economic sectors ...) through pressures (climate and anthropogenic) to states (environmental vulnerability) and impacts on ecosystems services and wellbeing, eventually leading especially to political responses. To apply the ISSE conceptual model, we combined the outputs of three models, (1) the EVI or environmental vulnerability index, (2) the SDSM model to determine climatic scenarios, and (3) the WEAP model, which aided to evaluate water demand for the urban population. This models lead to identify all the indicators of stress in the Upper Draa Valley. To accomplish this research we have devoted 3 years of research.

\section{Identification of environmental vulnerability indicators}

Assess environmental vulnerability using Environmental Vulnerability Index: The environmental vulnerability index (EVI) is designed to summarize a wide range of environmental vulnerability information. To achieve this index with 50 indicators, it was necessary to collect data from a variety of sources, including documents and government ministries. Information was also gathered through interviews with various organizations in UDV. The data gathered pertained to the environmental index. This later was determined for anthropogenic, meteorological, biological, and geological events and for general characteristics. The overall EVI for UDV was determined by the calculating 45 indicators from a total of 50, which is short of the $80 \%$ minimum requirement [18]. Data for the meteorological indices were obtained from the ORMVAO (Office Régional de Mise en Valeur Agricuole d'Ouarzazate) and ABHO (Agence du basin hydraulique d'Ouarzazate); and data for the biological, anthropogenic, and region characteristic indices were obtained primarily from Tourist Board, the National Board of Electricity and drinking water, and the Ministry of Energy. To be consistent with the methods of the South Pacific Applied Geosciences Commission, the calculation is done automatically through the data entry in the excel calculator provided freely in the website: http://www.vulnerabilityindex.net/ as detailed in Table 2, basing on the units of measurement used in last column in Table 2.

Assess climatic trends using the statistical downscaling model (SDSM): After Wilby and Dawson, the 'downscaling' techniques are used to bridge the spatial and temporal resolution gaps between what climate modelers are currently able to provide and what impact assessors require [19]. This paper uses a support tool for assessing local climate change impacts using a robust statistical downscaling technique. After the some researchers, Statistical Downscaling Model (SDSM) facilitates the rapid development of multiple, scenarios of daily surface weather variables under current and future regional climate forcing. SDSM develops an empirical relationship between a few selected large scale predictor variables (i.e. mean sea level pressure, wind velocity) and local scale predictands (i.e. precipitation and temperature) [20]. This downscaling method is recommended by Canadian Climate Impact Scenarios Project (CCIS) for climate change impact studies [21].

Table 3 gives a comparison of the evolution of climate and socioeconomic parameters in both scenarios used in this study A2 and B2.

Assess hydrological vulnerability using Water Evaluation and planning System (WEAP): WEAP (Water Evaluation and planning System) is created by Stockholm Environment Institue (SEI) by Jack Seiber, Water Systems Modeler; Chris Swartz, Research Associate and Annette Huber - Lee, Director Water Program (SEI). This model will help to identify water resource management options under different scenarios which in turn will help to identify and implement effective solutions to many water-related problems. All scenarios start from a common year, for which the model Current Accounts data are established [21]. We used three principal scenarios, which are: firstly the Reference scenario that represents the changes to occur in the future, in absence of any new policy measure. Base case scenario is with population growth at a rate of 3 in urban area [23]. And two other scenarios (scenarios of climate change) developed by SDSM model (A2 \& B2).

\section{A framework for analyzing vulnerability (ISSE model)}

The ISSE model (Figure 3) leads to understand how humans perceive the services provided by ecosystems, how these perceptions change behavior, and how these changes in turn feedback to affect ecosystem structure and function [24]. The model is made through the combination of the outputs of three programs (EVI, SDSM \& WEAP). These models address the linkages between ecosystem services (ES) and human outcomes and behavior, and how they influence each other in arid ecosystem. The work will be conducted by developing site-specific feedback model (Figure 3), developed in 2007 under the US-LTER strategic research initiative "Integrative Science for Society and the Environment" (ISSE) [24].

\section{Q1 to Q6 refer to the framework questions which are as follow:}

Q1: How do long-term press disturbances and short-term pulse disturbances interact to alter ecosystem structure and function?

Q2: How can biotic structure be both a cause and consequence of ecological fluxes of energy \& matter?

Q3: How do altered ecosystem dynamics affect ecosystem services?

Q4: How do changes in vital ecosystem services alter human outcomes?

Q5: How do perceptions and outcomes affect human behavior?

Q6: Which human actions influence the frequency, magnitude, or form of press and pulse disturbance?

In this paper we assess how climate change and anthropogenic has affected biodiversity, ecosystems, and ecosystem services and what is the human behavior to response (reaction) of these changes.

\section{Results}

\section{Identification of environmental vulnerability indicators}

Environmental vulnerability profile: Based on the analysis of the data collected, the overall environmental vulnerability index (EVI) for the UDV was determined to be 278 (with $90 \%$ of data). The Hazards index was determined to be 2.67 , the resistance index was 3.38 , and the damage index was found to be 2.57 .

The individual scores for each of the indicators used to determine the overall index are illustrated in Figure 4 and Table 2 (in Gray color). It should be noted that the vulnerability indices calculated were subject

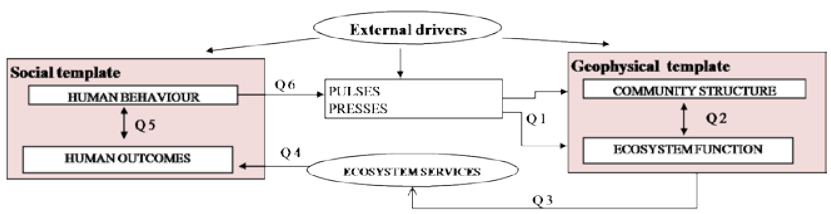

Figure 3: The ISSE framework: Socio-ecological system [24]. 
Citation: Karmaoui A, Messouli M, Ifaadassan I, Khebiza MY (2014) A Multidisciplinary Approach to Assess the Environmental Vulnerability at Local Scale in Context of Climate Change (Pilot Study in Upper Draa Valley, South Morocco). Global J Technol Optim 6: 167. doi: 10.4172/22298711.1000167

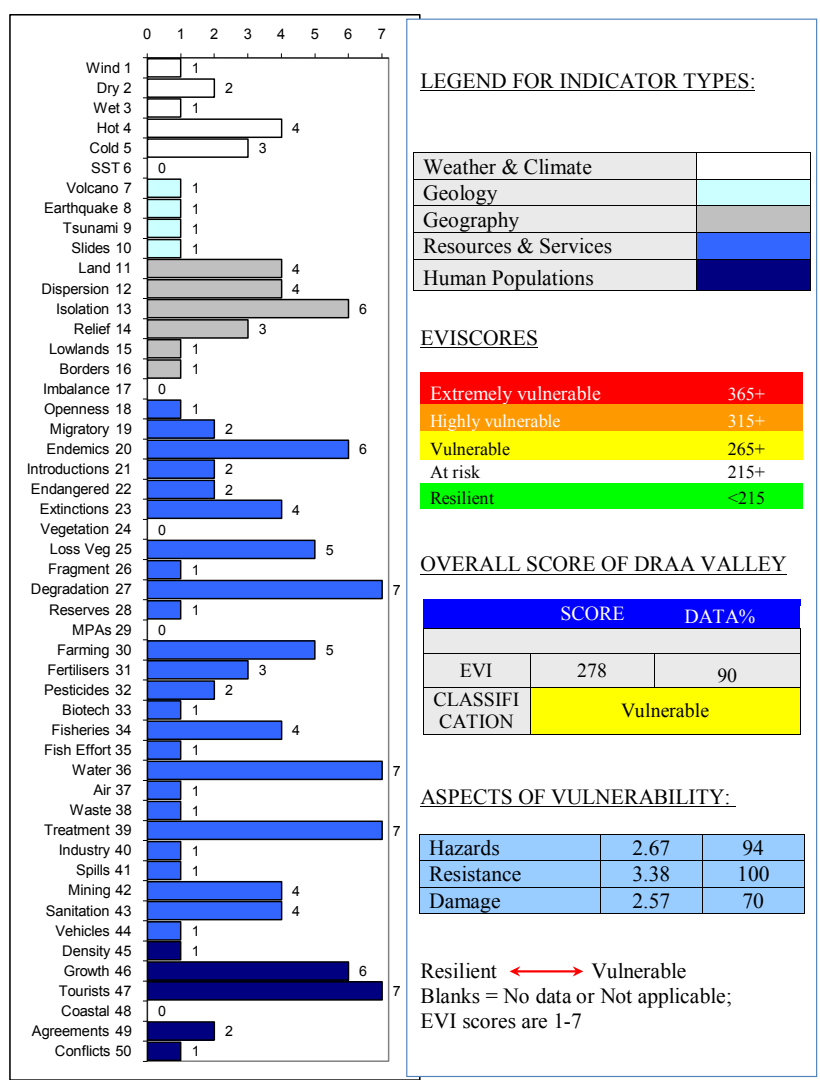

Figure 4: Environmental vulnerability profile of Upper Draa Valley.

to observation error, given that the data were not derived solely from field data but in many cases from previously documented data sources and for the indicators are not available data can influence the total score [25]. Because of the dynamic nature of the environment, this EVI is not a fixed value, and it can change in the future to reflect changes in the environmental.

The extraction and compilation of data from the Upper Draa Valley profile (Figure 4) allows us to classify vulnerability indicators in five sub-indices or categories as showed in graphs presented in Figures 5a (weather and Climate), 5b (geologic), 5c (geographic), 5d (anthropogenic) and 5e (resources \& services). These graphs compare the level of vulnerability of the indicators of each sub-index. The most important vulnerability issues for the Upper Draa Valley, those scoring a 6 and 7 on the EVI scale and identified using the EVI, relate to Isolation (Indicator number 13), Endemics (20), Degradation (27), Water (36), Treatment (39), Growth (46) and Tourist (47). The indicators scored a 4-5 on the EVI scale in several other areas that represent the next most vulnerable aspects this zone. These included, Hot (4), Land (11), Dispersion (12), Extinction (23), Loss veg (25), Farming (30), Fisheries (34), Mining (42) and Sanitation (43). The overall EVI score for the UDV is 278 vulnerable (Figure 4) and the detailed scores of the al vulnerability indicators, suggests that this area is, on a level, vulnerable to climate change and anthropogenic impacts, since the impact on factors related to climatic factors (water, loss vegetation and farming) and anthropogenic impact (endemic, extinction, fisheries, mining, sanitation, treatment, degradation, population growth and tourist pressure).

We can also rank the indicators under seven categories. The Figure
6 gives a comparative summary of seven vulnerability category. The climate change is the first category it was calculated to be 2.8 , the biodiversity was 2,87, the Exposure to Natural Disaster index was measured at 1.6, the Desertification was found to be 3.4, Agriculture/ Fisheries is 2,93, Human Health Aspects is 4, and Water 3.83 (Figure 6).

The Figure 6 shows that soil (desertification) and water are the most vulnerable. The importance of these services (water and soil) is related to the fact that entering in the maintenance and the support of all other ecosystem services, including provisioning services like food, fiber and genetic resources; regulating services such as waste and water purification, erosion control, climatic control and pollination, and cultural services like tourism, Spiritual, religious and aesthetic values).

\section{Trends of climatic parameters (mean temperature and pre-} cipitation)

The calculation of future climate anomalies (2010-2050) relative to the current climate (1961-2000) for mean temperature and precipitation lead to obtain the following results (Figures 7 and 8 ). The Figure 7 illustrate that under A2 and B2, the SDSM model predict a decrease in annual precipitation. Through this figure, we see that under A2 the coming years are dryer than under B2 scenario.

The Figures 7 illustrate that under A2 and B2, the SDSM model predict an increase in mean temperature under $\mathrm{A} 2$ and $\mathrm{B} 2$ with an increase more important under A2 during the period 2000-2050.

These results show increased temperature and decreased precipitations for the mentioned period in the Upper Draa Valley.

Trends of population growth and of water demand in urban area using Water Evaluation and planning System (WEAP)

All the urban data concerning water use in Upper Draa valley was compiled, and incorporated into the WEAP model, for the Ouarzazate city, the biggest city in Draa Basin. The Figure 9 shows the population growth rate in Ouarzazate city in the period 2010-2050, projected by the WEAP model.

The Figure 9 presents the possible development of Ouarzazate city inhabitants from 2010 to 2050 as calculated by WEAP model. For axis see table below (Table 4).

The Figure 10 shows the water demand of the Ouarzazate city in Million Cubic Meter (MCM). The model predicts an increase of water demand in Ouarzazate city from $2.3 \mathrm{Mm}^{3}$ in 2010 to $3 \mathrm{Mm}^{3}$ in 2015 and 7, $3 \mathrm{Mm}^{3}$ in 2030 under reference scenario. Comparing the water demand between reference, climate change B2 and A2 scenarios, we can obtain the following result (Figure 10 and Table 4).

The Table 5 (extracted from the Figure 10) gives a quantitative comparison of water demand of the Ouarzazate city under 3 scenarios in three selective years.

The water demand in this city will increase from $2.3 \mathrm{Mm}^{3}$ in 2010 to $4,1 \mathrm{Mm}^{3}$ in 2020 and 7, $3 \mathrm{Mm}^{3}$ in 2030 under climate change A2 scenario; and from $2.3 \mathrm{Mm}^{3}$ in 2010 to $3,7 \mathrm{Mm}^{3}$ in 2020 and $6 \mathrm{Mm}^{3}$ in 2030 under climate change B2 scenario.

\section{Framework for analyzing environmental vulnerability}

The ISSE model is a framework for analyzing vulnerability. It analyze the degree to which humans subsequently change personal or institutional behaviors and the degree to which these behaviors then influence ecological systems complete the causal loop. Both models 
Citation: Karmaoui A, Messouli M, Ifaadassan I, Khebiza MY (2014) A Multidisciplinary Approach to Assess the Environmental Vulnerability at Local Scale in Context of Climate Change (Pilot Study in Upper Draa Valley, South Morocco). Global J Technol Optim 6: 167. doi: 10.4172/22298711.1000167

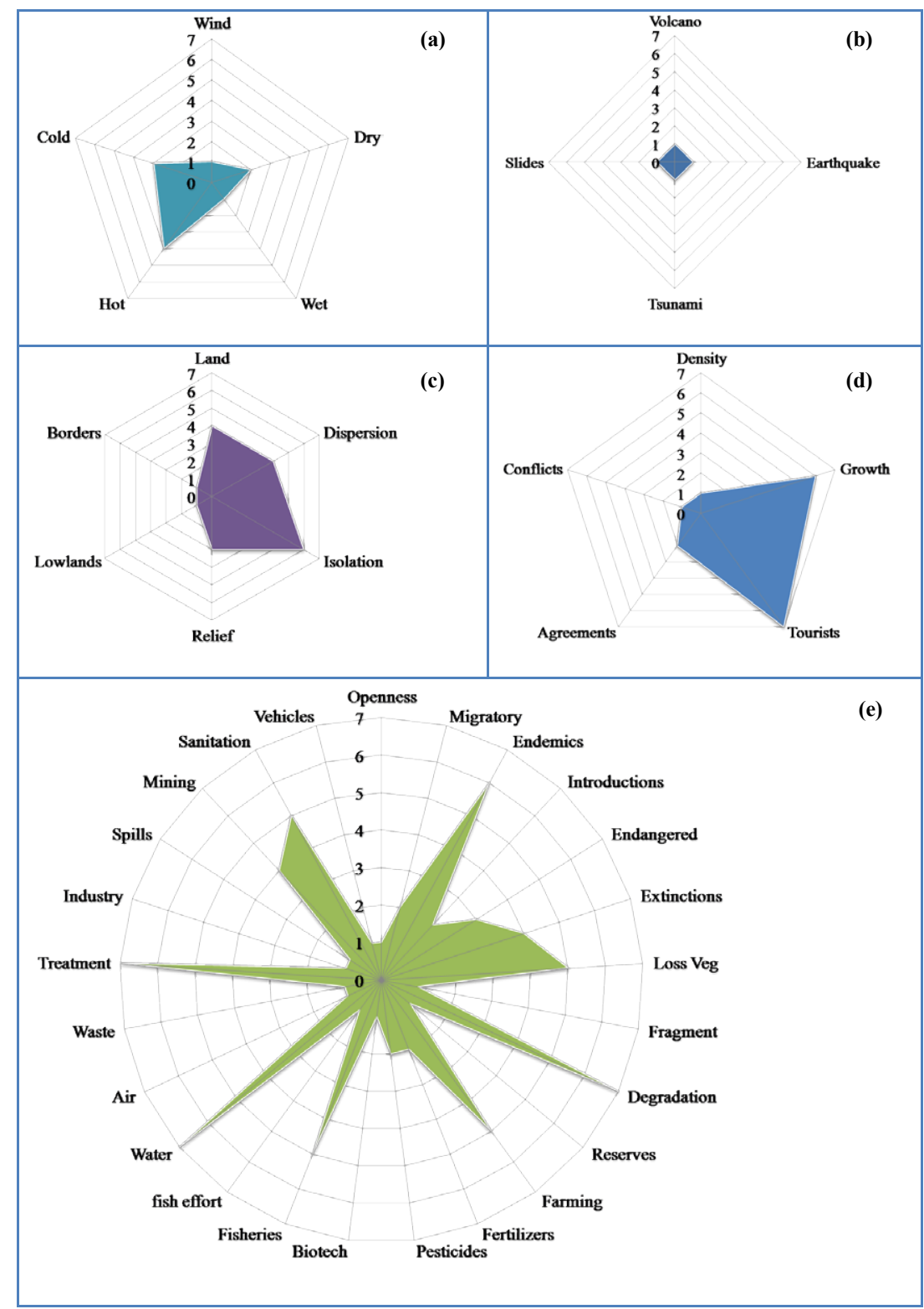

Figure 5: Vulnerability Indicators extracted and grouped into seven categories: sub-indices.; $5 \mathrm{a}$ (weather and Climate), 5b (geologic), $5 \mathrm{c}$ (geographic), 5d (anthropogenic) and 5e (resources \& services). The indicators used in this figure are described in Table 2.

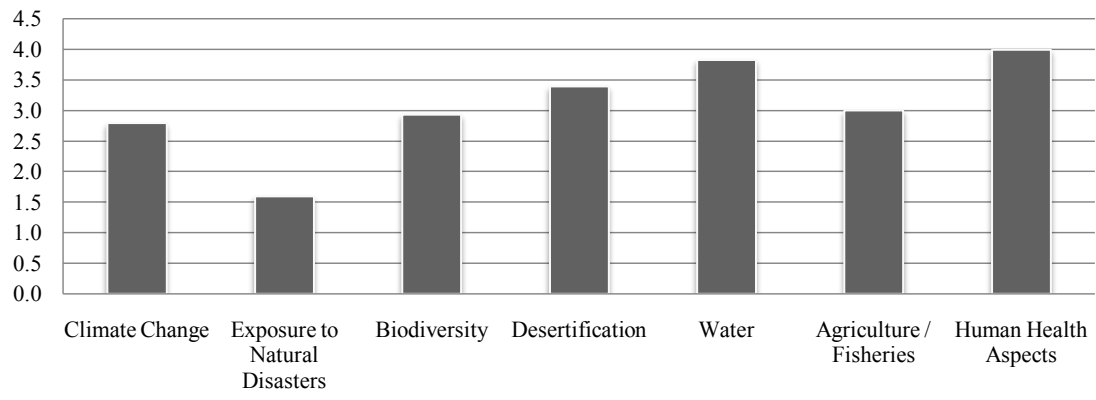

Figure 6: Environmental vulnerability category scores for the Upper Draa Valley. 
Citation: Karmaoui A, Messouli M, Ifaadassan I, Khebiza MY (2014) A Multidisciplinary Approach to Assess the Environmental Vulnerability at Local Scale in Context of Climate Change (Pilot Study in Upper Draa Valley, South Morocco). Global J Technol Optim 6: 167. doi: 10.4172/22298711.1000167

Page 8 of 11

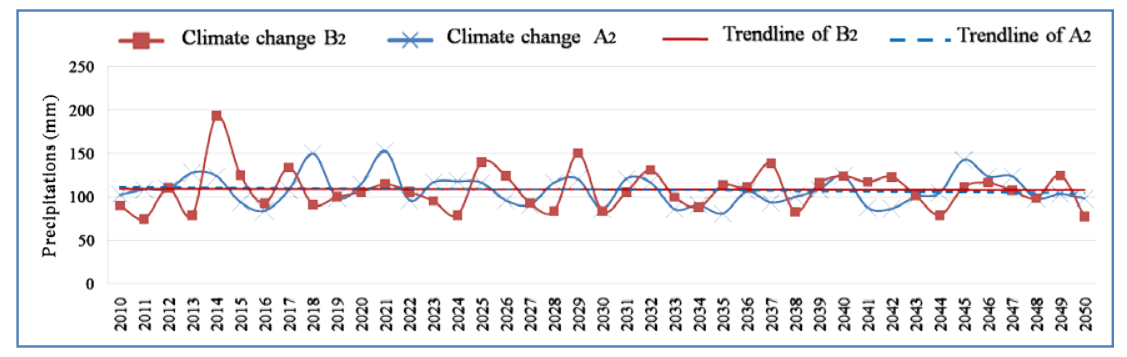

Figure 7: Sequence of total annual precipitations for A2 and B2scenarios during the period (2010-2050).

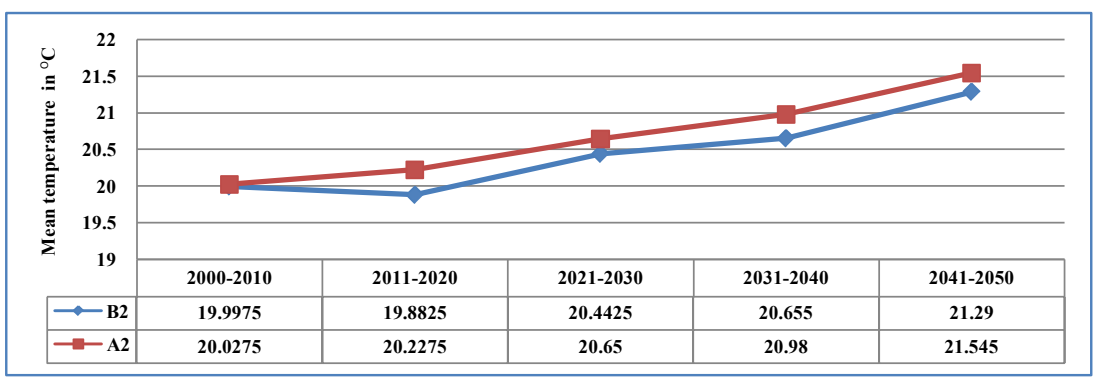

Figure 8: Mean temperature under A2 and B2 scenarios in the period of 2000-2050.

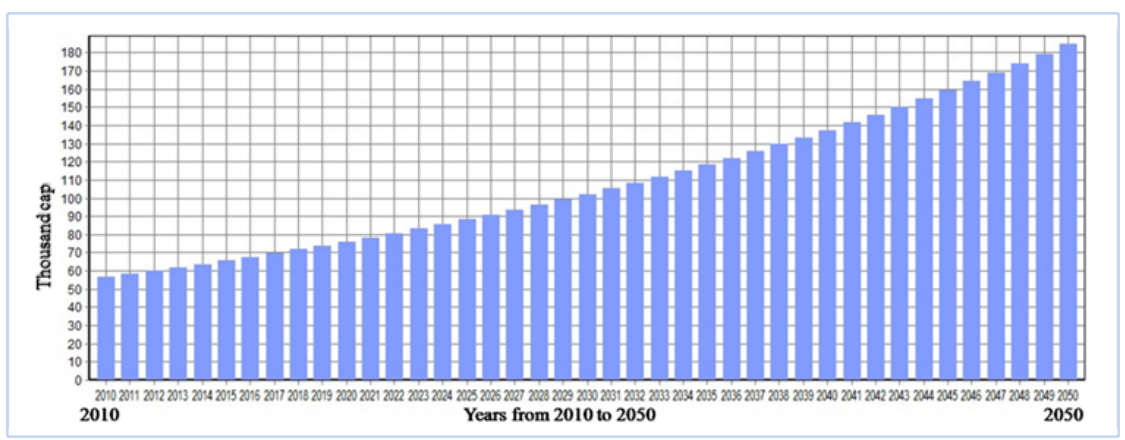

Figure 9: Population growth rate in Ouarzazate city in the period 2010-2050.

\begin{tabular}{|c|c|c|}
\hline Storylines & A2 scenario & B2 scenario \\
\hline $\begin{array}{c}\text { Regionalization } \\
\text { (heterogeneous world) }\end{array}$ & $\begin{array}{c}\text { regionally oriented } \\
\text { economic development }\end{array}$ & local environmental sustainability \\
\hline Population growth & medium & medium \\
\hline GDP growth & medium/high & medium \\
\hline Energy use & low & medium \\
\hline Land-use changes & slow & medium \\
\hline Resource availability & regional & medium \\
\hline Chace and direction of technological & "dynamics as usual" \\
\hline
\end{tabular}

Table 3: Overview of A2 and B2 scenarios parameters (Cited by [22]).

\begin{tabular}{|c|c|c|c|c|}
\hline Year & $\mathbf{2 0 1 0}$ & $\mathbf{2 0 2 0}$ & $\mathbf{2 0 3 0}$ & $\mathbf{2 0 5 0}$ \\
\hline Population & 56,6 & 76,1 & 102,3 & 137,4 \\
\hline
\end{tabular}

Table 4: Possible development of Ouarzazate city inhabitants from 2010 to 2050.

\begin{tabular}{|l|c|c|c|}
\hline Scenarios & $\mathbf{2 0 1 0}$ & $\mathbf{2 0 2 0}$ & $\mathbf{2 0 3 0}$ \\
\hline Climate Change A2 $\left(\mathrm{Mm}^{3}\right)$ & 2,3 & 4,1 & 7.3 \\
\hline Climate Change B2 $\left(\mathrm{Mm}^{3}\right)$ & 2,3 & 3,7 & 6 \\
\hline Reference $\left(\mathrm{Mm}^{3}\right)$ & 2,3 & 3,1 & 16 \\
\hline
\end{tabular}

Table 5: Water demand in million $\mathrm{m}^{3}\left(\mathrm{Mm}^{3}\right)$ of the Ouarzazate city under 3 scenarios in 2010, 2020, 2030 and 2050. 
Citation: Karmaoui A, Messouli M, Ifaadassan I, Khebiza MY (2014) A Multidisciplinary Approach to Assess the Environmental Vulnerability at Local Scale in Context of Climate Change (Pilot Study in Upper Draa Valley, South Morocco). Global J Technol Optim 6: 167. doi: 10.4172/22298711.1000167

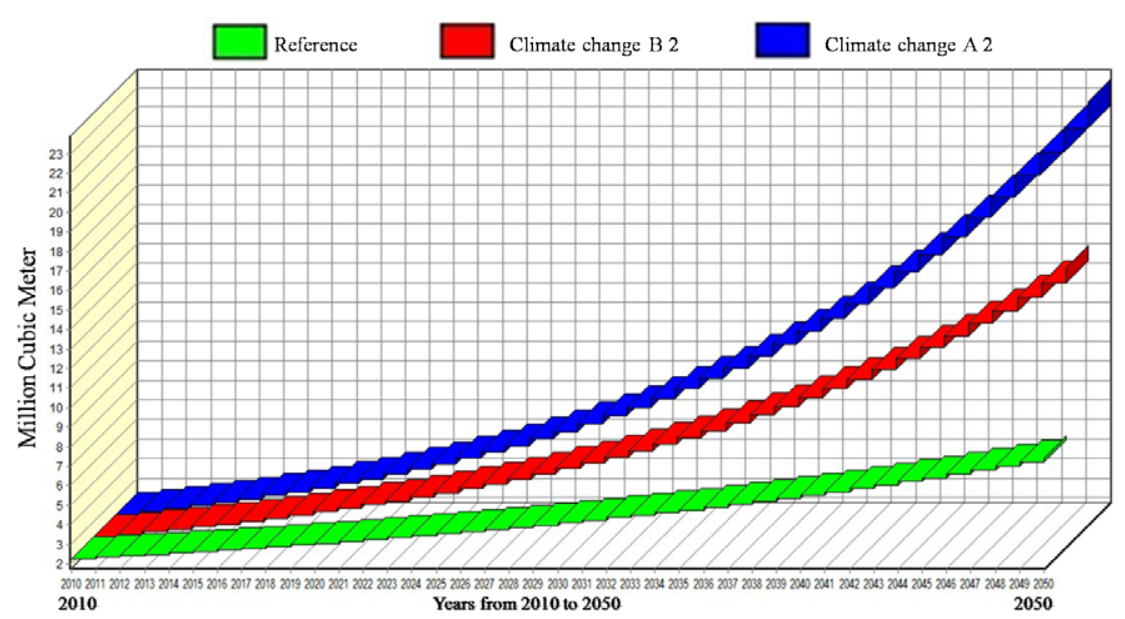

Figure 10: Water demand (fresh water consumption) in million $\mathrm{m} 3$ of the Ouarzazate city, under reference and climate change scenarios (A2 and B2), not including loss and water reuse, all months (12), from 2010 to 2050

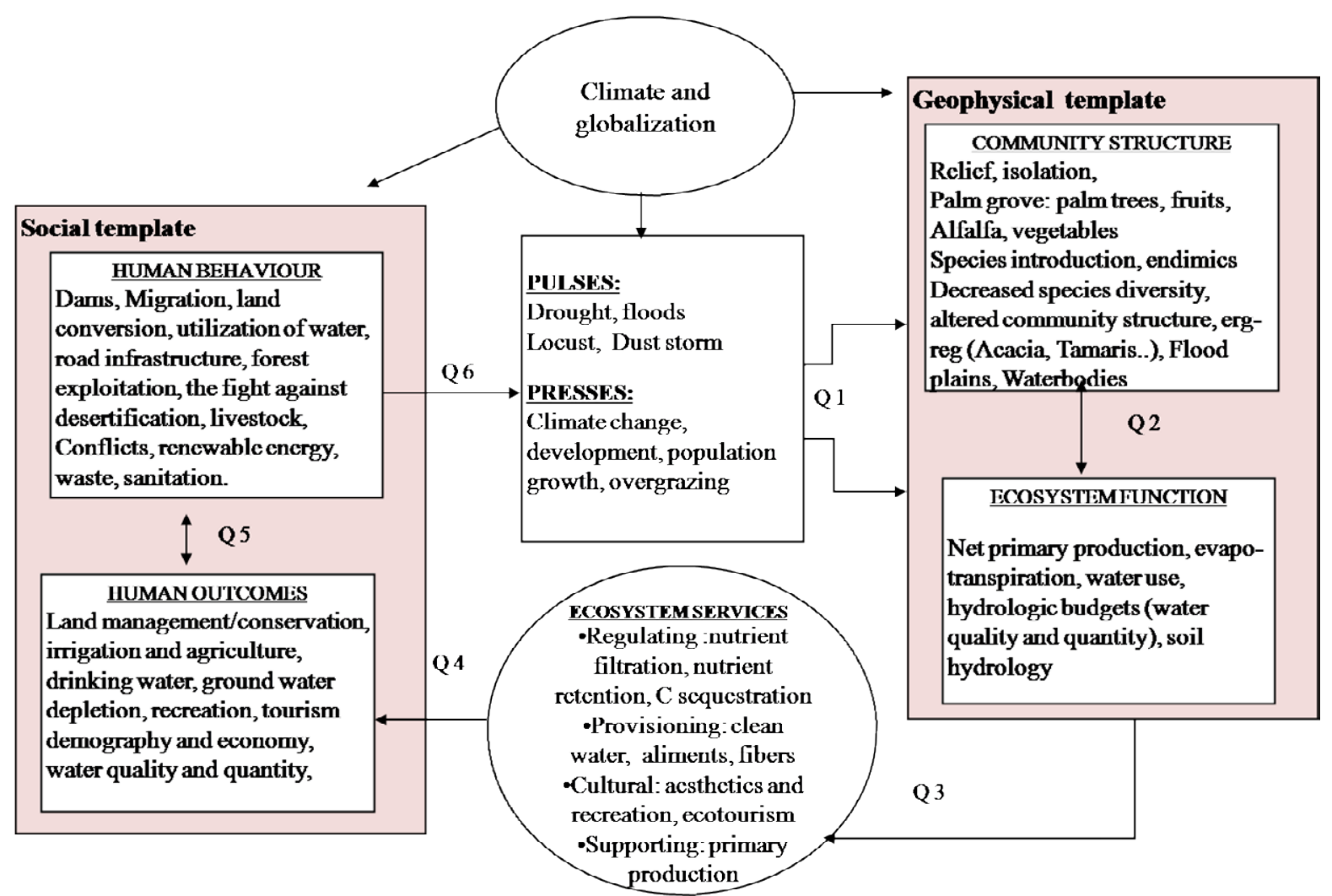

Figure 11: The ISSE framework. The right-hand side represents the domain of traditional ecological research; the left-hand side represents human dimensions of environmental change; the two are liked by the services provided by ecosystems (at bottom), and by pulse and press disturbances influenced or caused by human behavior (at top).

SDSM and WEAP can demonstrate on the fact that this region is and will be influenced by climate change and population pressure. This pressure could change the trajectory of ecosystems and their goods and services of the UDV. Because the population is directly linked with natural resources, the quality of these ecosystems is related to how the man responds, or not being aware of the impact that may result from its reaction. Focusing on interactive changes and stresses in the UDV, we can obtain the following conceptual model (Figure 11).

Climate change is expected to influence crop and livestock production, hydrologic balances, input sup-plies and other components of agricultural systems [26]. However, the nature of these biophysical effects and the human responses to them are complex like is mentioned in figure 12. For example, primary production is directly affected by changes in temperature and precipitation and the severity 
Citation: Karmaoui A, Messouli M, Ifaadassan I, Khebiza MY (2014) A Multidisciplinary Approach to Assess the Environmental Vulnerability at Local Scale in Context of Climate Change (Pilot Study in Upper Draa Valley, South Morocco). Global J Technol Optim 6: 167. doi: 10.4172/22298711.1000167

of extreme events like droughts, floods, and wind storms. In addition, carbon dioxide has the potential to increase the productivity of agroecosystems. Climate change may also change the types, frequencies, and intensities of various crop and livestock pests; the availability and timing of irrigation water supplies; and the severity of soil erosion [27]. Agricultural systems are managed ecosystems. Thus, the human response is critical to understanding and estimating the effects of climate change on production and food supply [28].

\section{Discussion}

The overall EVI score for the UDV is 278 , suggests that this area is, on a level, vulnerable to climate change and anthropogenic impacts. The most important vulnerability issues for this area, those scoring a 6 and 7 on the EVI scale and identified using the EVI, relate to Isolation (13), Endemics (20), Degradation (27), Water (36), Treatment (39), Growth (46) and Tourist (47). The indicators scored a 4-5 on the EVI scale in several other areas that represent the next most vulnerable aspects this zone. These included, Hot (4), Land (11), Dispersion (12), Extinction (23), Loss veg (25), Farming (30), Fisheries (34), Mining (42), Sanitation (43). It should be noted that most of these issues are in some way related to human activities. UDV socio-ecological system is subject to high rates of change in climate and/or other socio-ecological factors. Vulnerability analysis offers an approach for exploring implications of environmental and social changes [29]. The article gives a useful analysis of arid ecosystems vulnerability by analyzing interactions between social and natural systems. The methodology used illustrate and examine multiple and interacting stresses, by identifying and sometimes quantifying an important number of vulnerability indicators. A holistic understanding of vulnerability requires analysis of these many indicators and their interactions, along with an understanding of how the socio-ecological system in question adapt to the changes brought about by these factors. The vulnerability analyses reveal where actions can best be taken to enhance adaptive capacity. These actions should be on the basis of the available knowledge and the outputs of new analytical tools and methodologies like the combination of the four models used in this paper. Today, we must speak of a "participatory and integrated management", based on the participation of local populations (integrate indigenous knowledge) in order to promote environmental stability and security in ecosystem services. Scientific knowledge is also fundamental such climate modeling and downscaling, water modeling, scenarios for societal trends, environmental monitoring, and additional approaches integrating socio-ecological systems like the Driver-Pressure-StateImpact-Response (DPSIR) framework of the European Environment Agency and other institutions (EEA/OECD) and the ISSE framework developed in this paper. This methods and tools can help perfecting the understanding of the vulnerability stresses. The results of climate downscaling analyses illustrate how temperature and precipitation may change in this region. The projections presented were calculated using SDSM. To synthesize on future climate, the temperatures are likely to rise while precipitation is likely to decrease. Both the risk and the duration of droughts are likely to increase in this region. Water scarcity is increased by population growth. The information produced is important for the decision-makers. The WEAP software trace trends of water demand under different societal and climatic conditions. The water resources are becoming scarce due precipitation decrease and temperature increase. UDV is facing growing population and increased urbanization. Under the scenarios A2 and B2, the WEAP model predicts dryer conditions. The hydrologic model forecast that the water demand in urban area (Ouarzazate city) will increase greatly and available water will decrease due to dry years predicted in this paper both under A2\&B2. This article is based on the conceptual model developed by Collins et al [30]. This framework illustrates how human systems interact with the two main structural factors: climate and characteristics of landscape disturbance. To develop and validate the model, an analysis of its components was made using the three tools (EVI, SDSM and WEAP) treated in this paper. Changes in factors affecting ecosystems in this area, such as drought, demography, change in land use, etc.., Can lead to changes in factors directly affecting ecosystems, such as the decline in rainfall overexploitation of natural resources, etc.. The resulting changes in these ecosystems generate changes in ecosystem services and affecting elements of human wellbeing. The combination of 4 tools (EVI, SDSM, WEAP and ISSE) can serve as a multidisciplinary approach for conceptualizing and implementing sustainable development at local scale.

\section{Conclusion}

Methods and models used in this paper for vulnerability analysis lead to identify indicators of stress. The relevant data were obtained from available documents and data provided by governments and agencies. These data were gathered and compiled to calculate the values of the environmental indicators. The results of the research reveal that this region is vulnerable to climate change and anthropogenic impacts. The indicators received scores of 6 and 7, which indicated a high vulnerability, are Isolation (13), Endemics (20), Degradation (27), Water (36), Treatment (39), Growth (46) and Tourist (47). Those are mostly anthropogenic in origin and accelerated by climate change. Effectively the climate conditions and their trends, impact the water resources, which are the support of all ecosystem services and human activities. The challenges posed by climate change increase the importance of the UDV adaptation. The outputs of this three models (EVI, WEAP, SDSM) serves as a basis of the ISSE model, leading to a holistic understanding of vulnerability, in a coupled humanenvironment dimension.

\section{Acknowledgement}

We would like to thank SEI for the WEAP software license granted to the first author. We would also like to thank Dr. Babqiqi Abdelaziz for providing climatic data, Sefriti Abdelhak, Khattabi Ahmed, Kabiri Hafid \& Hamouzaki Youssef for their insightful and helpful comments and their time and interest in our work.

\section{References}

1. Walther GR, Post E, Convey P, Menzel A, Parmesan C, et al. (2002) Ecological responses to recent climate change. Nature 416: 389-395.

2. Parmesan C, Yohe G (2003) A globally coherent fingerprint of climate change impacts across natural systems. Nature 421: 37-42.

3. Root TL, Price JT, Hall KR, Schneider SH, Rosenzweig C, et al. (2003) Fingerprints of global warming on wild animals and plants. Nature 421: 57-60.

4. Africa progress report (2014) Grain Fish Money, Financing Africa's Green and Blue Revolutions 9: 183.

5. Solomon S, Qin D, Manning M, Alley RB, Berntsen T, et al. (2007) Climate change 2007: the physical science basis, Cambrige: Intergovernmental Panel on Climate Change.

6. Margat J, Treyer S (2004) L'eau des Méditerranéens: situation et perspectives UNEP-MAP (Mediterranean Action Plan) Technical Report, 158: 366.

7. Busche $H(2012)$ Modeling hydrological processes in a semi-arid mountainous catchment at the regional scale, Dissertation, Bonn, August 2012.

8. Diekkruger B, Busche $\mathrm{H}$, Klose A et al. (2010) Impact of Global Change on hydrology and soil degradation-Scenario analysis for the semi-arid Drâa catchment (South Morocco). The Global Dimensions of Change in River Basin 5-13. 
Citation: Karmaoui A, Messouli M, Ifaadassan I, Khebiza MY (2014) A Multidisciplinary Approach to Assess the Environmental Vulnerability at Local Scale in Context of Climate Change (Pilot Study in Upper Draa Valley, South Morocco). Global J Technol Optim 6: 167. doi: 10.4172/22298711.1000167

9. Stanners D, Bourdeau P (1995) Europe's environment: The Dobrís assessment, Luxemburg: European Environmental Agency.

10. Messouli M, Salem AB, Ghallabi B, Yacoubi-Khebiza M, Boughrous AA, et al. (2009) Ecohydrology and groundwater resources management under global change: A pilot study in the pre-Saharan basins of southern Morocco, In Options Méditerranéennes, Technological Perspectives for Rational Use of Water Resources in the Mediterranean Region, Marakech, pp. 255-264

11. Gommes R, Kanamaru H, El hairech T, Rosillon D, Babqiqi A, et al. (2008) World Bank - Morocco study on the impact of Climate change on the agricultural sector, FAO component: impacts on crop yields, FAO and Agricultural Ministry of Morocco, Maroc. p.105.

12. Rochdane S (2014) Vulnérabilité au changement climatique au Maroc: Sécurité alimentaire nationale et profils de vulnérabilité environnementale et hydrique du bassin versant Rheraya. Thèse de Doctorat. LHEA, Faculté des Sciences Semlalia-Marrakech. Cadi Ayyad University, Morocco 200p.

13. Cappy S (2006) Hydrogeological characterization of the Upper Drâa catchment Morocco, Unpublished PhD thesis, Geological Institute, Faculty of Mathematics and Natural Sciences, University of Bonn.

14. Piqué A (2001) Geology of Northwest Africa.Berlin: Gebrueder Bornträger

15. Klose A (2009) Soil characteristics and soil erosion by water in a semi-arid catchment (Wadi Drâa, South Morocco) under the pressure of global change. Angefertigtmit Genehmigung der Mathematisch-Naturwissenschaftlichen Fakultät der Rheinischen Friedrich-Wilhelms-Universität Bonn.

16. Graf K (2010) Drinking water supply in the Middle Draa Valley, Soouth Morocco Options for action in the context of water scaricity and institutional conntraints, 34 .

17. PACC (2011), Oasis et Zones Arides Résilientes Territoires Engagés.

18. EVI (2003) The Demonstration Environmental Vulnerability Index (EVI) South Pacific Applied Geoscience Commission April 2003, SOPAC Technical Report 356. By: Ursula Kaly, Craig Pratt, Jonathan Mitchell and Russell Howorth.

19. Robert L. Wilby and Christian W Dawson (2004) Using SDSM Version 3.1-A decision support tool for the assessment of regional climate change impacts,
User Manual supported by the Environment Agency of England and Wales as part of the Climate Impacts and Adaptation Research Programme.

20. Koukidis EN, Berg AA (2009) Sensitivity of the Statistical Downscaling Model (SDSM) to reanalysis products, Atmosphere-Ocean 47: 1-18.

21. Dibike YB, Gachon P, St-Hilaire A, Ouarda TBMJ, Van TV Nguyen (2007) Uncertainty analysis of statistically downscaled temperature and precipitation regimes in Northern Canada, Theoritical and Applied Climatology 91: 149-170.

22. Rochdane S, Reichert B, Messouli M, Babqiqi A, Yacoubi Khebiza M (2012) Climate change impacts on water supply and demand in Rheraya Watershed (Morocco), with potential adaptation strategies Water 4: 28-44.

23. RGPH, 2004. Recensement général de la population et de I'habitat. Haut commissariat au plan du Maroc.

24. US-LTER (2007) U.S. Long Term Ecological Research Network (LTER), The Decadal Plan for LTER: Integrative Science for Society and the Environment, 54:154.

25. Gowrie MN (2003) Environmental vulnerability index for the island of Tobago West Indies. Conservation Ecology, 7(2): 11

26. Apata TG, Samuel KD, Adeola AO (2009) Analysis of climate change perception and adaptation among arable food crop farmers in South Western Nigeria. In Contributed paper prepared for presentation at the international association of agricultural economists' 2009 conference, Beijing, China, August 16 (Vol. 22).

27. Ernest LM, Cornelius ML (2007) The Economic Impact of Climate Change on Agriculture in Cameroon. The World Bank. Development Research Group. Sustainable Rural and Urban Development Team September 2007.

28. Adams RM, Hurd BH, Lenhart S, Leary N (1998) Effects of global climate change on agriculture: An interpretative review, Climate Research 11(1): 19-30.

29. Committee I (2012). Future climate change vulnerability assessments in the Arctic

30. Collins S.L (2007) Integrative science for society and environment: a strategic research initiative. LTER. 